Meryem Taoufik ${ }^{1}$, Meriem Laghlimi² ${ }^{2}$ Ahmed Fekri ${ }^{3}$

\title{
Comparison of Land Surface Temperature Before, During and After the Covid-19 Lockdown Using Landsat Imagery: A Case Study of Casablanca City, Morocco
}

\begin{abstract}
Land Surface Temperature (LST) is an important variable within global climate change. With the appearance of remote sensing techniques and advanced GIS software, it is now possible to estimate LST. In this study, the effect of lockdown during COVID-19 on the LST was assessed using Landsat 8 Imagery. LST dynamic was investigated for three different periods: Before, during and after the COVID-19 lockdown. The study was conducted in Casablanca City. The results showed that during the emergence of COVID-19 with lockdown policy applied, the LST decreases remarkably compared to the previous 4-years' average LST. After the easing of restrictions, the LST increased to exceed the previous 4-year mean LST. Furthermore, throughout all studied periods, the LST recorded its higher values in industrial zones and areas with high urban density and urban transportation, which indicates the conspicuous impact of anthropogenic activities on the LST variation. These findings indicate an ability to assess the feasibility of planned lockdowns intended as a potential preventive mechanism to reduce LST peaks and the loss of air quality in metropolitan environments in the future.
\end{abstract}

Keywords: Land Surface Temperature, Landsat 8, COVID-19, spatiotemporal analysis, Remote Sensing, Morocco

Received: 1 February 2021; accepted: 23 February 2021

(C) 2021 Authors. This is an open access publication, which can be used, distributed and reproduced in any medium according to the Creative Commons CC-BY 4.0 License.

1 Laboratory of Applied Geology, Geomatics and Environment, Faculty of Sciences Ben M'Sik, Hassan II University of Casablanca, Casablanca, Morocco, email: meryem.taoufik@gmail.com (corresponding author)

ORCID ID: https://orcid.org/0000-0001-8572-3459

2 Laboratory of Applied Geology, Geomatics and Environment, Faculty of Sciences Ben M'Sik, Hassan II University of Casablanca, Casablanca, Morocco, email: laghlimi.meriem@gmail.com ORCID ID: https://orcid.org/0000-0003-0192-075X

3 Laboratory of Applied Geology, Geomatics and Environment, Faculty of Sciences Ben M'Sik, Hassan II University of Casablanca, Casablanca, Morocco, email: ahmedfekri13@gmail.com 


\section{Introduction}

The 2019 novel coronavirus, also known as SARS-CoV-2, is one of the major pathogens that primarily targets the human respiratory system [1]. COVID-19 was first reported in the Huanan seafood market in the city of Wuhan, China, late December 2019 [2]. Many of the initial 41 cases reported exposure to seafood and live animals in the Huanan Seafood Market [3]. However, the zoonotic origin of SARS-CoV-2 is not yet confirmed [4]. According to phylogenetic trees, SARS-CoV is closer to SARS-like bat CoVs [5]. Subsequently, human-to-human transmission was confirmed and quickly spread globally. The disease is being exported to a growing number of countries and has caused an increasing number of deaths around the world [6]. On March 11, the World Health Organization (WHO) upgraded the status of the COVID-19 outbreak from epidemic to pandemic [7]. Despite efforts to limit its spread, COVID-19 cases had increased drastically in many countries. According to the last report published by the WHO, a total of 4,287,981,729,406 confirmed cases have been recorded around the world, including 1,022,397 deaths [8].

The first case of COVID-19 in Morocco was confirmed on 2 March 2020. In order to develop preventive strategies and limit the spread of the virus in the country, authorities implemented several measures and imposed a strict curfew on the $20^{\text {th }}$ March. However, the number of infections escalated rapidly after the easing of COVID-19 restrictions since $23^{\text {rd }}$ May. In fact, the number of infection cases continued to climb rapidly, reaching 353,803 confirmed cases, 5,789 deaths, and 302,314 recovered by November 2020.

In response to directives from the Moroccan government, transit going all through Moroccan cities was restricted, most transportation was prohibited, and many outdoor human activities were banned (restaurants, parks, shopping malls, gyms, schools and universities were all closed), as well as all extracurricular activities. In addition, some large manufacturing companies suspended their operations to avoid the possibility of COVID-19 transmission. These measures are certainly beneficial, since they help reduce the infection and the mortality by COVID-19, but has a negative impact on the economic situation, particularly in terms of socio-economic relations [9].

Although some studies have been made on the effect of the COVID-19 pandemic on ecology in some Moroccan cities, no research could be found regarding the effect of the COVID-19 induced lockdown situation on the Land Surface Temperature (LST). Previous studies have shown a more specific interest in air quality assessment, especially $\mathrm{NO}_{2}, \mathrm{PM}_{2.5}, \mathrm{PM}_{10^{\prime}} \mathrm{CO}$ and $\mathrm{SO}_{2}$, based on ground station site data [10]. Actually, LST is an interesting environmental variable that has been widely investigated in many studies, such as climate change, environment, agriculture, hydrology and urban planning [11-14]. According to [15, 16], LST is directly linked to transportation, industrial and residential activities. References [17] and [18] have established a correlation among several factors, such as anthropogenic 
issues on LST. Other studies have underlined that LST variations may have many impacts on ecological system balance, human life and energy cycles [19-21]. The impact of COVID-19 induced lockdown on the changes of air quality and land surface temperature has been already discussed in the literature. Reference [22] reported an overall decrease in LST values in Dehradun City, India, during the post-COVID lockdown time. Another research conducted in Wuhan City, China, by [23] reveals that during the COVID-19, the mean LST was lower than the mean LST of the last three years on the same dates. Meanwhile, during the emergence of COVID-19 without a lockdown strategy, the mean LST was comparatively higher than the mean LST of the last three years. This research also highlighted that the mean LST of built-up areas witnessed the most important variations during the COVID-19 lockdown in comparison to the average of the last three years.

The city of Casablanca is the industrial and economic center of Morocco. During the strict lockdown, commercial, industrial activities and transportation were prohibited. After the easing of restrictions, Casablanca recorded the highest number of COVID-19 infections and fatalities, and remains the worst-hit in Morocco. For this reason, the authorities have chosen to maintain the lockdown and strict preventive measures to control the virus' spread. The aim of this study is to assess the variation of the LST before and during the emergence of coronavirus, with regards to the lockdown policy in Casablanca.

\section{Materials and Methods}

\subsection{Study Area}

Casablanca city is located in the central-western part of Morocco between $33.65^{\circ}$ and $33.68^{\circ}$ north latitude and $-7.44^{\circ}$ and $-7.44^{\circ}$ east longitude (Fig. 1). Bordered by the Atlantic Ocean, the city has a Mediterranean climate with a strong oceanic tendency, which gives it rather wet, mild winters and warm, dry summers.

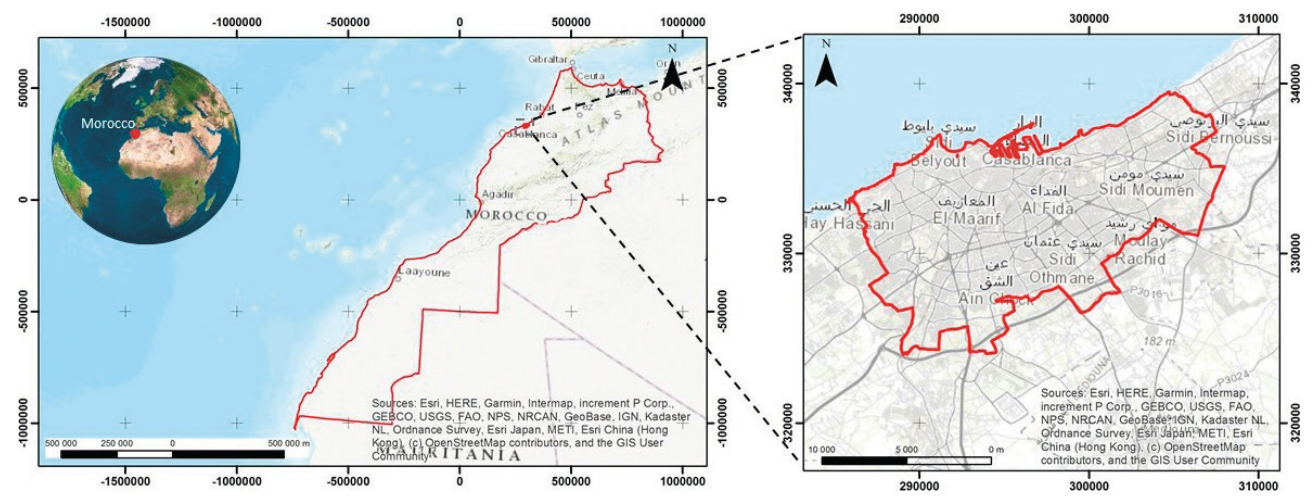

Fig. 1. Location of the study area 
The annual average temperature is $18.88^{\circ} \mathrm{C}$ and the annual cumulative precipitation is $426.1 \mathrm{~mm}$. Casablanca is the most populous city in Morocco and has a population of about 3.71 million in the urban area. Considered as the economic and business center of Morocco, the city hosts the leading Moroccan companies and many other international corporations doing business in the country, as well as the main industrial facilities. Thereby, Casablanca holds its recorded position as the primary industrial zone of Morocco.

\subsection{Data Collection}

This study was performed using satellite data gathered from the United States Geological Survey USGS website https://earthexplorer.usgs.gov/ (Tab. 1). Landsat 8 is a satellite that aims at monitoring the Earth's surface through the recording of multispectral images, in order to produce information for use in environmental monitoring, protection and sustainability of the planet; it is equipped with two sensors, the Operational Land Imager (OLI) multispectral sensor and the Thermal Infrared Sensor (TIRS) [24]. Landsat 8 OLI and TIRS images are free and have Thermal Infrared (TIRS) bands (Band 10 and 11).

Thirty-three multi-date Landsat images (path: 202, row: 27) are used for this study. The satellite images were level 1 GeoTIFF type.

Table 1. Landsat image characteristics used in this research

\begin{tabular}{|c|c|c|c|}
\hline Band & Sensor & $\begin{array}{c}\text { Spectral resolution } \\
{[\mu \mathrm{m}]}\end{array}$ & $\begin{array}{c}\text { Spatial resolution } \\
{[\mathrm{m}]}\end{array}$ \\
\hline Band 1 - Coastal/Aerosol & \multirow{9}{*}{ OLI } & $0.433-0.453$ & 30 \\
\hline Band 2 - Visible blue (BLUE) & & $0.450-0.515$ & 30 \\
\hline Band 3 - Visible green (GREEN) & & $0.525-0.600$ & 30 \\
\hline Band 4 - Visible red (RED) & & $0.630-0.680$ & 30 \\
\hline Band 5 - Near-infrared (NIR) & & $0.845-0.885$ & 30 \\
\hline Band 6 - Short wavelength infrared 1 (SWIR1) & & $1.56-1.66$ & 30 \\
\hline Band 7 - Short wavelength infrared 2 (SWIR2) & & $2.10-2.30$ & 30 \\
\hline Band 8 - Panchromatic & & $0.50-0.68$ & 15 \\
\hline Band 9 - Cirrus & & $1.36-1.39$ & 30 \\
\hline Band 10 - Thermal Infrared (TIRS) 1 & \multirow{2}{*}{ TIRS } & $10.3-11.3$ & 100 \\
\hline Band 11 - Thermal Infrared (TIRS) 2 & & $11.5-12.5$ & 100 \\
\hline
\end{tabular}




\subsection{Data Description}

This study compares three different periods, before, during and after the COVID-19 induced lockdown in Morocco, based on Landsat 8 OLI and TIRS images. As the lockdown started on $20^{\text {th }}$ March, the chosen periods are between the $1^{\text {st }}$ January and $20^{\text {th }}$ March for the 'pre-lockdown' period, between the $21^{\text {th }}$ March and the $23^{\text {rd }}$ May for the 'during lockdown' period, and between the $24^{\text {rd }}$ May and $8^{\text {th }}$ June for the 'after easing COVID-19 restrictions' period. On the other hand, in order to better understand the variation of the LST, images of the same periods were analyzed for the years 2016, 2017, 2018 and 2019. The historical data (Tab. 2) allows us to avoid any confusion between the variations due to regular seasonal changes, and the possible variations caused by the lockdown policies.

For this study, dates were chosen based on the availability of data and also on the cloud cover. The data acquired between January and June occur during winter and spring, which may represent significant spots of clouds on images. Therefore, images were not selected based on exactly the same dates, but on their quality in order to avoid the influence of clouds and obtain more representative results.

Table 2. Acquisition dates and characteristics of satellite images

\begin{tabular}{|c|c|c|c|c|c|}
\hline Year & $\begin{array}{l}\text { Period } \\
(\mathrm{P})\end{array}$ & $\begin{array}{l}\text { Acquisition } \\
\text { date }\end{array}$ & Image ID & Cycle & Path/Row \\
\hline \multirow{8}{*}{2016} & P1 & 2016-01-06 & LC08_L1TP_202037_20160106_20170404_01_T1 & Daytime & $202 / 37$ \\
\hline & P2 & 2016-01-22 & LC08_L1TP_202037_20160122_20170405_01_T1 & Daytime & $202 / 37$ \\
\hline & P3 & 2016-02-07 & LC08_L1TP_202037_20160207_20170330_01_T1 & Daytime & $202 / 37$ \\
\hline & P4 & $2016-02-23$ & LC08_L1TP_202037_20160223_20180527_01_T1 & Daytime & $202 / 37$ \\
\hline & P5 & 2016-10-03 & LC08_L1TP_202037_20160310_20170328_01_T1 & Daytime & $202 / 37$ \\
\hline & P6 & 2016-03-26 & LC08_L1TP_202037_20160326_20170327_01_T1 & Daytime & $202 / 37$ \\
\hline & P8 & 2016-04-27 & LC08_L1TP_202037_20160427_20170326_01_T1 & Daytime & $202 / 37$ \\
\hline & P11 & 2016-05-29 & LC08_L1TP_202037_20160529_20180527_01_T1 & Daytime & $202 / 37$ \\
\hline \multirow{5}{*}{2017} & P3 & 2017-02-09 & LC08_L1TP_202037_20170209_20170217_01_T1 & Daytime & $202 / 37$ \\
\hline & P6 & 2017-03-29 & LC08_L1TP_202037_20170329_20170414_01_T1 & Daytime & $202 / 37$ \\
\hline & P7 & 2017-04-14 & LC08_L1TP_202037_20170414_20170501_01_T1 & Daytime & $202 / 37$ \\
\hline & P8 & 2917-04-30 & LC08_L1TP_202037_20170430_20170515_01_T1 & Daytime & $202 / 37$ \\
\hline & P10 & $2017-05-16$ & LC08_L1TP_202037_20170516_20170525_01_T1 & Daytime & $202 / 37$ \\
\hline
\end{tabular}


Table 2. cont.

\begin{tabular}{|c|c|c|c|c|c|}
\hline Year & $\begin{array}{l}\text { Period } \\
(\mathrm{P})\end{array}$ & $\begin{array}{l}\text { Acquisition } \\
\text { date }\end{array}$ & Image ID & Cycle & Path/Row \\
\hline \multirow{6}{*}{2018} & P1 & 2018-01-11 & LC08_L1TP_202037_20180111_20180119_01_T1 & Daytime & $202 / 37$ \\
\hline & P2 & 2918-01-27 & LC08_L1TP_202037_20160310_20170328_01_T1 & Daytime & $202 / 37$ \\
\hline & P3 & 2018-02-12 & LC08_L1TP_202037_20180212_20180222_01_T1 & Daytime & $202 / 37$ \\
\hline & P6 & 2018-04-01 & LC08_L1TP_202037_20180401_20180416_01_T1 & Daytime & $202 / 37$ \\
\hline & P7 & 2018-04-17 & LC08_L1TP_202037_20180417_20180501_01_T1 & Daytime & $202 / 37$ \\
\hline & P11 & 2018-06-04 & LC08_L1TP_202037_20180604_20180615_01_T1 & Daytime & $202 / 37$ \\
\hline \multirow{6}{*}{2019} & P1 & 2019-01-14 & LC08_L1TP_202037_20190114_20190131_01_T1 & Daytime & $202 / 37$ \\
\hline & P3 & 2019-02-15 & LC08_L1TP_202037_20190215_20190222_01_T1 & Daytime & $202 / 37$ \\
\hline & P5 & 2019-03-19 & LC08_L1TP_202037_20190319_20190325_01_T1 & Daytime & $202 / 37$ \\
\hline & P7 & 2019-04-20 & LC08_L1TP_202037_20190420_20190507_01_T1 & Daytime & $202 / 37$ \\
\hline & P8 & 2019-05-06 & LC08_L1TP_202037_20190506_20190521_01_T1 & Daytime & $202 / 37$ \\
\hline & P11 & 2019-06-07 & LC08_L1TP_202037_20190607_20190619_01_T1 & Daytime & $202 / 37$ \\
\hline \multirow{8}{*}{2020} & P1 & 2020-01-01 & LC08_L1TP_202037_20200101_20200113_01_T1 & Daytime & $202 / 37$ \\
\hline & P2 & 2020-01-17 & LC08_L1TP_202037_20200117_20200128_01_T1 & Daytime & $202 / 37$ \\
\hline & P3 & 2020-02-02 & LC08_L1TP_202037_20200202_20200211_01_T1 & Daytime & $202 / 37$ \\
\hline & P6 & $2020-03-21^{*}$ & LC08_L1TP_202037_20200202_20200211_01_T1 & Daytime & $202 / 37$ \\
\hline & P7 & 2020-04-06 & LC08_L1TP_202037_20200406_20200410_01_T1 & Daytime & $202 / 37$ \\
\hline & P8 & 2020-04-22 & LC08_L1TP_202037_20200508_20200526_01_T1 & Daytime & $202 / 37$ \\
\hline & P10 & 2020-05-08 & LC08_L1TP_202037_20200508_20200526_01_T1 & Daytime & $202 / 37$ \\
\hline & P11 & 2020-05-24 & LC08_L1TP_202037_20200524_20200607_01_T1 & Daytime & $202 / 37$ \\
\hline
\end{tabular}

* Lockdown was started on the $20^{\text {th }}$ March 2020; hence P7 to P10 represent during lockdown period and P11 represents the after lockdown period. 


\subsection{Land Surface Temperature Extraction}

LST is calculated using the following steps described below and illustrated in Figure 2.

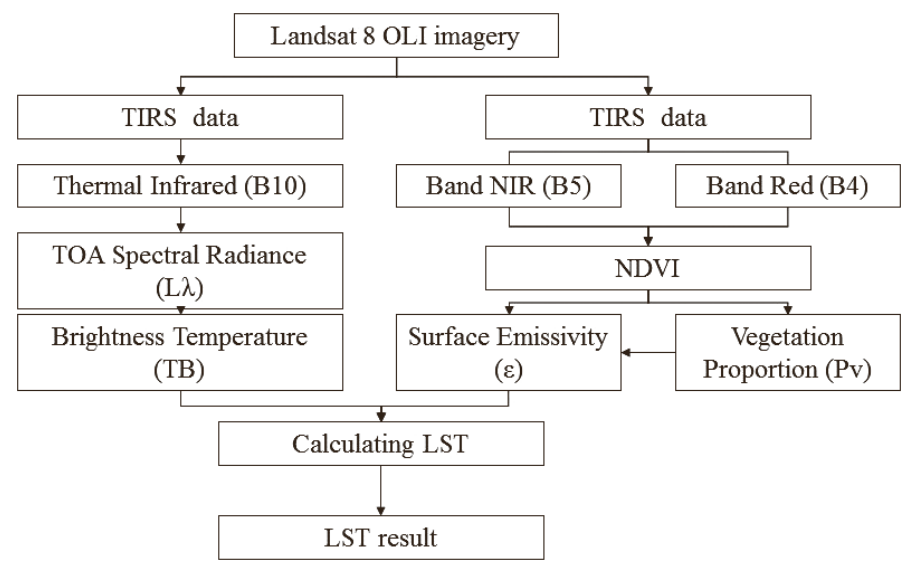

Fig. 2. Flowchart for LST retrieval

\section{TOA Spectral Radiance}

The value of TOA Spectral Radiance ( $L \lambda)$ of TIRS Band 10 is estimated using the algorithm given below. This algorithm (1) transforms raw image into spectral radiance image [25]:

$$
L \lambda=M_{L} \times Q_{\text {cal }}+A_{L}
$$

where $L \lambda$ is the spectral radiance [watts $\left./\left(\mathrm{m}^{-2} \cdot \mathrm{s} \cdot \mathrm{rad}^{-1} \cdot \mu \mathrm{m}^{-1}\right)\right], M_{L}$ represents the band-specific multiplicative rescaling factor, $Q_{\text {cal }}$ is the Band 10 image, and $A_{L}$ is the band-specific additive rescaling factor provided in the metadata file of the Landsat image.

\section{Brightness Temperature}

Brightness temperature (BT) is the microwave radiation radiance traveling upward from the top of Earth's atmosphere [26]. In order to convert reflectance to BT, the following equation (2) is adopted [25], using the thermal constants provided in the metadata file of the Landsat image:

$$
\mathrm{BT}=\frac{K_{2}}{\ln \left[\left(K_{1} / L \lambda\right)+1\right]}-273.15
$$

where $\mathrm{BT}$ is the brightness temperature, $K_{1}$ and $K_{2}$ are thermal conversion constants, and $L \lambda$ is top of atmospheric radiance. 
In order to obtain the results in Celsius, the radiant temperature is revised by adding the absolute zero (approx. $-273.15^{\circ} \mathrm{C}$ ) [27].

\section{Land Surface Emissivity}

The land surface emissivity $(\operatorname{LSE}(\varepsilon))$ must be calculated in order to estimate LST, since the LSE is a proportionality factor that scales blackbody radiance (Planck's law) to predict emitted radiance, and it is the efficiency of transmitting thermal energy across the surface into the atmosphere [28]. The $\operatorname{LSE}(\varepsilon)$ can be stated as the equation below:

$$
\operatorname{LSE}(\varepsilon)=0.004 \cdot P_{v}+0.986
$$

where $P_{v}$ is the proportion of vegetation obtained according to [29]:

$$
P_{v}=\left(\frac{\mathrm{NDVI}-\mathrm{NDVI}_{s}}{\mathrm{NDVI}_{v}-\mathrm{NDVI}_{s}}\right)^{2}
$$

where NDVI is the normalized difference vegetation index, calculated using the combination of band near infrared (Band 5) and red (Band 4), as follow:

$$
\text { NDVI }=\frac{\text { Band } 5-\text { Band } 4}{\text { Band } 5+\text { Band } 4}
$$

$\mathrm{NDVI}_{s}$ (also called NDVI ${ }_{\text {min }}$ ) is the NDVI of soil, and NDVI (also called NDVI ${ }_{\text {max }}$ ) is the NDVI of vegetation.

\section{Land Surface Temperature}

The final step is to estimate the LST using the algorithm in Eq. (6) [30]:

$$
\mathrm{LST}=\frac{\mathrm{BT}}{\left\{1+\left[(\lambda \mathrm{BT} / \rho) \ln \varepsilon_{\lambda}\right]\right\}}
$$

where BT is the at-sensor brightness temperature, $\lambda$ is the TOA reflectance, and $\ln \varepsilon \lambda$ is the emissivity.

\section{Results and Discussion}

In this paper, the impact of the COVID-19 induced total lockdown on the LST was assessed using three time periods (between the $1^{\text {st }}$ January and the $20^{\text {th }}$ March "First total lockdown date", between the $21^{\text {th }}$ March and the $23^{\text {rd }}$ May "Date of easing of COVID-19 restrictions", and from the $24^{\text {th }}$ May to the $8^{\text {th }}$ June "After the 
easing of COVID-19 restrictions"). Each time frame was divided into periods of 16 days. In fact, the non-availability of data and the significance of cloud cover were limiting factors in this study. Therefore, the acquisition of different dates from different years was the solution to bypass this issue. Furthermore, an averaging process of the past four years' data was performed to reduce LST variation in a specific year before the emergence of COVID-19 in Morocco.

Periods $(\mathrm{P})$ are numbered from 1 to 11 and the LST of each year for each period is calculated following the main steps described in the 2.4. Land Surface Temperature Extraction section. The average LST is then estimated for the different periods. The obtained results are compared to the same dates of 2020 year (Tab. 3). It can be seen that the mean difference of the LST is not calculated for P4, P5 and P9 periods. Data from these time frames are not available for the year 2020, and were thus excluded from this research. One option would have been to estimate the LST based on the interpolation of previous and next 16-day data. However, this technique might have biased the results, especially for the P5 and P4 periods that will depend on the during lockdown data. For these reasons, P4, P5 and P9 are not represented in the final results.

Table 3. Descriptive LST statistics over the study periods

\begin{tabular}{|c|c|c|c|c|c|c|c|c|c|c|c|}
\hline \multirow{2}{*}{$\operatorname{LST}\left[{ }^{\circ} \mathrm{C}\right]$} & \multicolumn{5}{|c|}{ Before lockdown } & \multicolumn{5}{|c|}{ During lockdown } & \multirow{2}{*}{$\begin{array}{c}\begin{array}{c}\text { After } \\
\text { lockdown }\end{array} \\
\text { P11 }\end{array}$} \\
\hline & P1 & P2 & P3 & P4 & P5 & P6 & P7 & P8 & P9 & P10 & \\
\hline In 2016 & 15.56 & 17 & 11.03 & 19.14 & 12.71 & 22.54 & $x$ & 27.65 & $x$ & $\times$ & 23.81 \\
\hline In 2017 & $x$ & $x$ & 16.67 & $x$ & $x$ & 24.66 & 24.45 & 20.39 & $x$ & 30.12 & $x$ \\
\hline In 2018 & 14.98 & 11.18 & 17.09 & $x$ & $x$ & 22.55 & 25.48 & $x$ & $\times$ & $x$ & 24.1 \\
\hline In 2019 & 15 & $x$ & 15.02 & $x$ & 23.25 & $x$ & 23.49 & 26.57 & $x$ & $x$ & 26.52 \\
\hline $\begin{array}{l}\text { Average, } 4 \text { years } \\
\text { before } 2020\end{array}$ & 15.17 & 14.09 & 14.95 & 19.14 & 17.98 & 23.25 & 24.47 & 24.87 & $\times$ & 30.12 & 24.81 \\
\hline During 2020 & 15.46 & 14.93 & 20.49 & $\times$ & $x$ & 12.29 & 21.84 & 19.64 & $x$ & 22.64 & 33.26 \\
\hline Mean difference & -0.29 & -0.84 & -5.53 & $x$ & $x$ & 10.96 & 2.63 & 5.23 & $x$ & 7.475 & -8.45 \\
\hline
\end{tabular}

$\times$ - data has significant cloud cover.

Figure 3 shows the comparison between during and before the emergence of COVID-19, over the time frame of the study. As can be noted, the average LST of 2020 is slightly higher than the average LST of the four previous years. Actually, 
the mean differences of $\mathrm{P} 1, \mathrm{P} 2$ and $\mathrm{P} 3$ are $-0.29^{\circ} \mathrm{C},-0.84^{\circ} \mathrm{C}$ and $-5.53^{\circ} \mathrm{C}$, respectively (Tab. 3). In contrast, the first period after total lockdown (P6), the gap becomes larger, represented by $10.96^{\circ} \mathrm{C}$ of difference. In addition, the average LST of 2020 tends to stay under the 4-years' average LST till the easing of COVID-19 restrictions. Indeed, once the Moroccan government declared the resumption of some economic sectors on the $20^{\text {th }}$ May, several economic operators resumed their activities while respecting health measures. Accordingly, the resumption caused heavy traffic in the metropolis, and traffic jams were noticed at certain crossings in the city [31]. Thus, the P11 is marked by a sharp rise in the LST of 2020, and the mean difference reaches $-8.45^{\circ} \mathrm{C}$. In other words, there is a noticeable correlation between the LST variation and the COVID-19 induced lockdown during the three different stages.

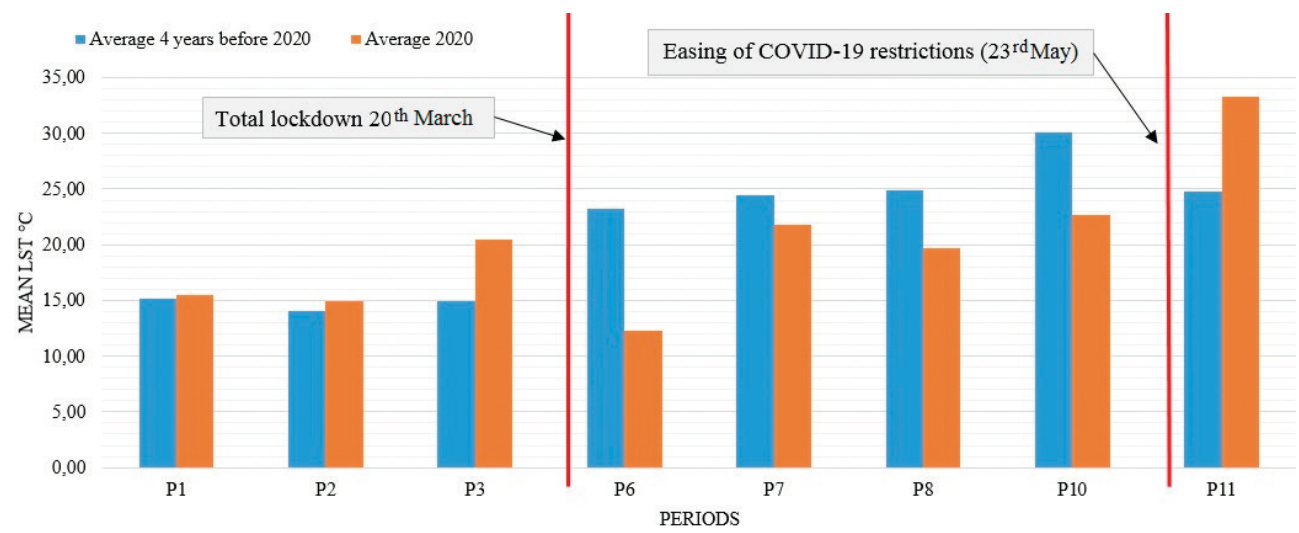

Fig. 3. Mean LST comparison between before, during and after the total lockdown

The aggregation of the mean LST before the application of the lockdown policy during the COVID-19 period, as well as the average of the past four years before the emergence of COVID-19 on the same dates, is illustrated by Figure 4. Image processing and maps' creation were done using ArcGIS 10.3. The interval classes of LST are set to be reliable for each compared period so that spatio-temporal comparisons could be easily explored.

One might argue that there is a clear spatio-temporal variation of LST during the three stages, especially during the lockdown period. According to Figure $4 \mathrm{a}$ and Figure $4 \mathrm{~b}$, representing the before lockdown period, it is evident that there is a great degree of similarity between the 4-year average LST and the LST of 2020 across the study area. In contrast, during the lockdown period represented in Figure 4c and Figure $4 \mathrm{~d}$, the 4-year average LST tended to exhibit relatively higher temperatures, while the LST of 2020 is more typically represented by green color rather than the orange color compared to previous years. On the contrary, after easing COVID-19 restrictions, LST jumped approximately $8^{\circ} \mathrm{C}$ and the orange color became the most dominant compared to the past four years (Fig. 4e, f). 


\section{Before lockdown}

a)

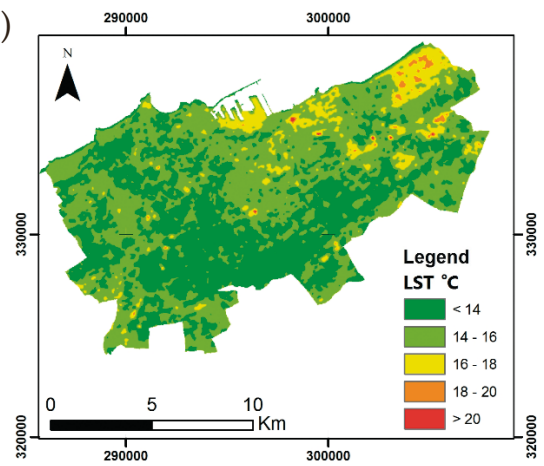

b)

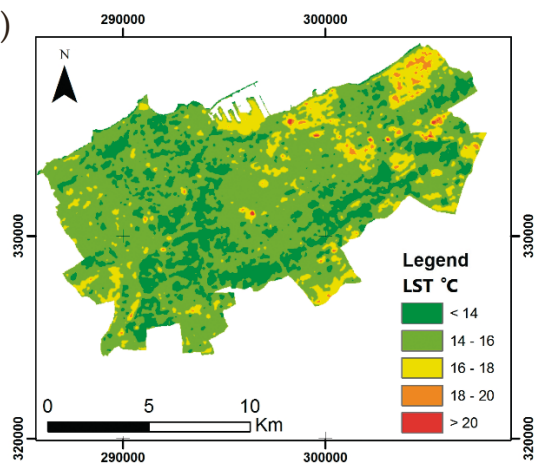

During lockdown

c)

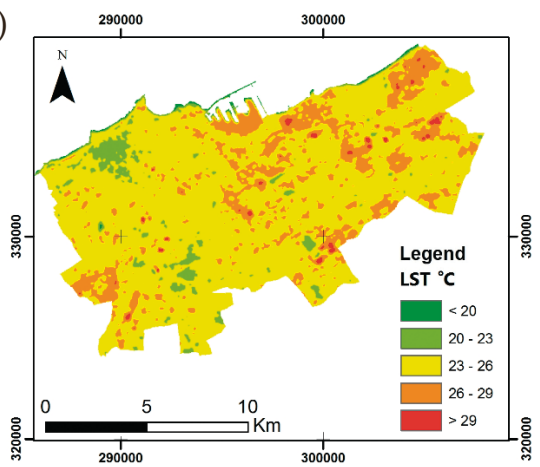

d)

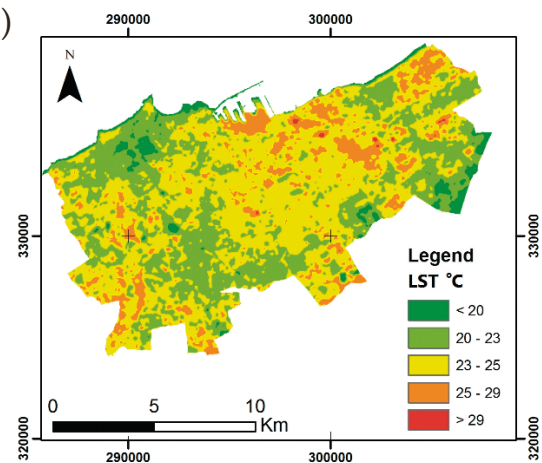

\section{After lockdown}

e)

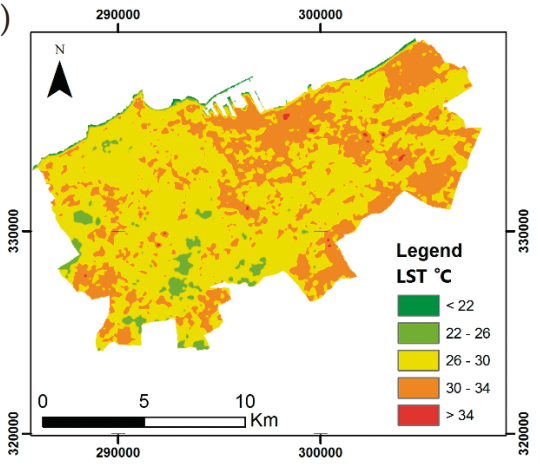

f)

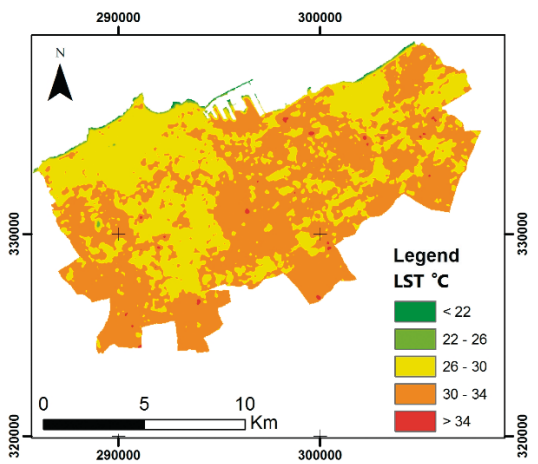

Fig. 4. LST comparison of the main three periods: before lockdown, during lockdown and after lockdown: the average LST of the past four years before the emergence of COVID-19 (a, c, e); the LST of $2020(b, d, f)$ 
In general, these findings are in agreement with results published in the literature, highlighting the impact of industrial activities and transportation on the LST change [32]. In addition, the urban heat islands (UHI) are located in sectors characterized by a high density of buildings and very developed industrial activity, in particular the North-East of Casablanca (the industrial zone of Ain sebaa, Bernoussi, Tit mellil and Ain Harrouda), and the port of Casablanca in the North. These areas show the highest temperature values across the six-time frames. To better understand the distribution of the different land-cover patterns, Figure 5 shows the land use of the Casablanca region (adapted from [33]).

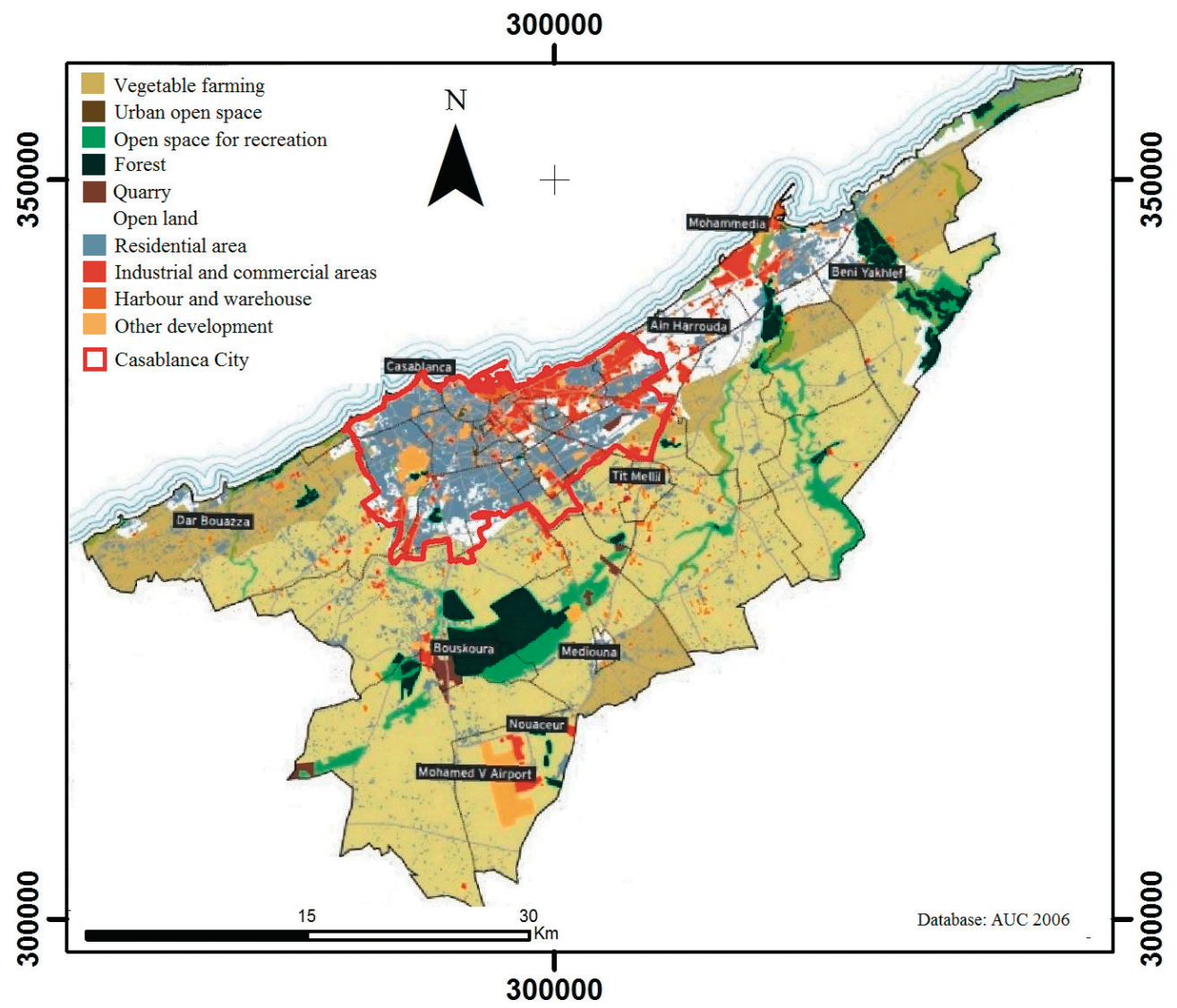

Fig. 5. Land use of Casablanca region

Source: adapted from [33]

These results not only show that the total lockdown had a direct impact on the LST, but also that the LST is not increasing simultaneously with the expansion of urban areas and the increase of population. In fact, the suppression of some anthropogenic activities may help controlling the LST to improve the environmental 
quality of the city. This implies that identifying land surface temperature contributes to better urban planning and partially prevents increases in temperatures and the urban heat island phenomenon in urban areas. This observation was also made previously by $[23,34]$.

\section{Conclusion}

In this study, the mean LST differences before, during and after the COVID-19 induced lockdown, and the average of the past four years for the same dates was assessed using Landsat 8 OLI data and remote sensing techniques. The results show that the average LST of the past four years has the same trend as the LST of 2020 for the same time frame representing before the emergence of COVID-19 in Casablanca. Once the lockdown policy applied in $20^{\text {th }}$ March, the LST of 2020 has decreased significantly, showing a mean difference of $10.96^{\circ} \mathrm{C}$. In fact, the LST of 2020 was lower than the mean LST of the past four years on the same dates during all the lockdown period. After the easing of COVID-19 restrictions, a remarkable increase is observed in LST of 2020. These findings could be better supported by applying the same methodology to other industrial cities in Morocco using higher spatial resolution data. This would confirm and emphasize the effective relation between the COVID-19 lockdown and the land surface temperature.

This research suggests that industrial activities, tourism, and transportation have a severe impact on LST, and indirectly on the environment. Therefore, in order to ensure favorable living conditions and the protection of environment from the negative effects of economic, industrial and other anthropogenic activities, the LST factor must be considered when planning land use. This parameter will contribute to the effective management of urban areas.

\section{References}

[1] Carlos W.G., Dela Cruz C.S., Cao B., Pasnick S., Jamil S.: Novel Wuhan (2019-nCoV) Coronavirus. American Journal of Respiratory and Critical Care Medicine, vol. 201, 2020, pp. 7-8.

[2] Wuhan Municipal Health Commission: Report on current pneumonia epidemic situation in the city. 2019. http://wjw.wuhan.gov.cn/front/web/showDetail/ 2019123108989 [access: 8.10.2020].

[3] Huang C., Wang Y., Li X., Ren L., Zhao J., Hu Y., Zhang L., Fan G., Xu J., Gu X., Cheng Z., Yu T., Xia J., Wei Y., Wu W., Xie X., Yin W., Li H., Liu M., Xiao Y., Gao H., Guo L., Xie J., Wang G., Jiang R., Gao Z., Jin Q., Wang J., Cao B.: Clinical features of patients infected with 2019 novel coronavirus in Wuhan, China. The Lancet, vol. 395, 2020, pp. 497-506. https://doi.org/10.1016/ S0140-6736(20)30183-5. 
[4] Cascella M., Rajnik M., Cuomo A., Dulebohn S.C., Di Napoli R.: Features, Evaluation and Treatment Coronavirus (COVID-19). StatPearls, 2020. https:// www.ncbi.nlm.nih.gov/books/NBK554776/ [access: 1.02.2021].

[5] Shereen M.A., Khan S., Kazmi A., Bashir N., Siddique R.: COVID-19 infection: Origin, transmission, and characteristics of human coronaviruses. Journal of Advanced Research, vol. 24, 2020, pp. 91-98. https://doi.org/10.1016/ j.jare.2020.03.005.

[6] World Health Organization: Coronavirus disease 2019 (COVID-19) Situation Report - 67. WHO, 2020. https://apps.who.int/iris/bitstream/handle/ 10665/331613/nCoVsitrep27Mar2020-eng.pdf?sequence=1\&isAllowed=y [access: 27.03.2020].

[7] World Health Organization: Coronavirus disease 2019 (COVID-19) situation report - 50. WHO, 2020. https://apps.who.int/iris/bitstream/handle/ 10665/331450/nCoVsitrep10Mar2020-eng.pdf?sequence=1\&isAllowed=y [access: 10.03.2020].

[8] World Health Organization: Weekly Operational Update on COVID-19: 30 November 2020. Interim Guidance, 2020. https://www.who.int/publications/m/ item/weekly-operational-update---30-november-2020 [access: 27.03.2020].

[9] Firano Z., Filali Adib F.: The COVID-19: macroeconomics scenarii and role of containment in Morocco. One Health, vol. 10, 2020, art. no. 100152. https://doi. org/10.1016/j.onehlt.2020.100152.

[10] Otmani A., Benchrif A., Tahri M., Bounakhla M., Chakir E.M., El Bouch M., Krombid M.H.: Impact of Covid-19 lockdown on $\mathrm{PM}_{10^{\prime}} \mathrm{SO}_{2}$ and $\mathrm{NO}_{2}$ concentrations in Salé City (Morocco). Science of the Total Environment, vol. 735, 2020, art. no. 139541. https://doi.org/10.1016/j.scitotenv.2020.139541.

[11] Wang C., Li Y., Myint S.W., Zhao Q., Wentz E.A.: Impacts of spatial clustering of urban land cover on land surface temperature across Köppen climate zones in the contiguous United States. Landscape and Urban Planning, vol. 192, 2019, art. no. 103668. https://doi.org/10.1016/j.landurbplan.2019.103668.

[12] Hu T., Renzullo L.J., Dijk A.I.J.M.v., He J., Tian S., Xu Z., Zhou J., Liu T., Liu Q.: Monitoring agricultural drought in Australia using MTSAT-2 land surface temperature retrievals. Remote Sensing of Environment, vol. 236, 2020, art. no. 111419. https://doi.org/10.1016/j.rse.2019.111419.

[13] Shah H.L., Zhou T., Huang M., Mishra V.: Strong Influence of Irrigation on Water Budget and Land Surface Temperature in Indian Subcontinental River Basins. IGR Atmospheres, vol. 124, issue 3, 2019, pp. 1449-1462. https://doi.org/ doi.org/10.1029/2018JD029132.

[14] Weng Q., Firozjaei M.K., Kiavarz M., Alavipanah S.K., Hamzeh S.: Normalizing land surface temperature for environmental parameters in mountainous and urban areas of a cold semi-arid climate. Science of The Total Environment, vol. 650, 2019, pp. 515-529. https://doi.org/10.1016/j.scitotenv.2018.09.027. 
[15] Zhana Q., Meng F., Xiao Y.: Exploring the relationships of between land surface temperature, ground coverage ratio and building volume density in an urbanized environment. The International Archives of the Photogrammetry, Remote Sensing and Spatial Information Sciences, vol. XL-7/W3, 2015, pp. 255-260. https://doi.org/10.5194/isprsarchives-XL-7-W3-255-2015.

[16] Amir Siddique M., Dongyun L., Li P., Rasool U., Ullah Khan T., Javaid Aini Farooqi T., Wang L., Fan B., Rasool M.: Assessment and simulation of land use and land cover change impacts on the land surface temperature of Chaoyang District in Beijing, China. PeerJ, vol. 8, 2020. https://doi.org/10.7717/peerj.9115.

[17] Buyantuyev A., Wu J.: Urban heat islands and landscape heterogeneity: linking spatiotemporal variations in surface temperatures to land-cover and socioeconomic patterns. Landscape Ecology, vol. 25, 2010, pp. 17-33. https://doi.org/10.1007/ s10980-009-9402-4.

[18] Li X., Li W., Middel A., Harlan S.L., Brazel A.J., Turner II B.L.: Remote sensing of the surface urban heat island and land architecture in Phoenix, Arizona: Combined effects of land composition and configuration and cadastral-demographic-economic factors. Remote Sensing of Environment, vol. 174, issue 1, 2016, pp. 233-243.

[19] Anderson M.C., Norman J.M., Kustas W.P., Houborg R., Starks P.J., Agam N.: A thermal-based remote sensing technique for routine mapping of land-surface carbon, water and energy fluxes from field to regional scales. Remote Sensing of Environment, vol. 112, 2008, pp. 4227-4241. https://doi.org/10.1016/ j.rse.2008.07.009.

[20] Brunsell N.A., Gillies R.R.: Length scale analysis of surface energy fluxes derived from remote sensing. Journal of Hydrometeorology, vol. 4, 2002, pp. 1212-1219.

[21] Smith T.M., Reynolds R.W., Peterson T.C., Lawrimore J.: Improvements to NOAA's Historical Merged Land-Ocean Surface Temperature Analysis (1880-2006). Journal of Climate, vol. 21, issue 10, 2008, pp. 2283-2296. https://doi.org/10.1175/2007JCLI2100.1.

[22] Maithani S., Nautiyal G., Sharma A.: Investigating the Effect of Lockdown During COVID-19 on Land Surface Temperature: Study of Dehradun City, India. Journal of the Indian Society of Remote Sensing, vol. 48, 2020, pp. 1297-1311. https://doi.org/10.1007/s12524-020-01157-w.

[23] Hadibasyir H.Z., Rijal S.S., Sari D.R.: Comparison of Land Surface Temperature During and Before the Emergence of Covid-19 using Modis Imagery in Wuhan City, China. Forum Geografi, vol. 34, issue 1, 2020. https://doi.org/10.23917/ forgeo.v34i1.10862.

[24] González-Márquez L.C., Torres-Bejarano F.M., Torregroza-Espinosa A.C., Hansen-Rodríguez I.R., Rodríguez-Gallegos H.B.: Use of LANDSAT 8 images for depth and water quality assessment of El Guájaro reservoir, Colombia. Journal of South American Earth Sciences, vol. 82, 2018, pp. 231-238. https://doi. org/10.1016/j.jsames.2018.01.004. 
[25] USGS: Using the USGS Landsat Level-1 Data Product. https://www.usgs.gov/ core-science-systems/nli/landsat/using-usgs-landsat-level-1-data-product [access: 1.02.2020].

[26] Latif M.S.: Land Surface temperature retrival of Landsat-8 data using split window algorithm - a case study of Ranchi district. International Journal of Engineering Development and Research, vol. 2, issue 4, 2014, pp. 3840-3849.

[27] X H.-Q.,Chen B.-Q.: Remote sensing of the urban heat island and its changes in Xiamen City of SE China. Journal of Environmental Sciences, vol. 16, issue 2, 2004, pp. 276-281.

[28] Jimenez-Munoz J.C., Sobrino J.A., Gillespie A., Sabol D., Gustafson W.T.: Improved land surface emissivities over agricultural areas using ASTER NDVI. Remote Sensing of Environment, vol. 103, issue 4, 2006, pp. 474-487.

[29] Carlson T., Ripley D.: On the relation between NDVI, fractional vegetation cover, and leaf area index. Remote Sensing of Environment, vol. 62, issue 3, 1997, pp. 241-252. https://doi.org/10.1016/S0034-4257(97)00104-1.

[30] Stathopoulou M.,Cartalis C.: Daytime urban heat islands from Landsat ETM+ and Corine land cover data: an application to major cities in Greece. Solar Energy, vol. 81, issue 3, 2007, pp. 358-368.

[31] Bouhrara I.: Etat d'urgence sanitaire 3: Casablanca, unereprise en douce. 2020. https://www.ecoactu.ma/etat-durgence-sanitaire-3-casablanca-reprise/ [access: 5.12.2020].

[32] Karimi A., Pahlavani P., Bigdeli B.: Land use analysis on Land Surface Temperature in urban areas using a geographically weighted regression and Landsat 8 imagery, a case study: Tehran, Iran. International Archives of the Photogrammetry, Remote Sensing and Spatial Information Sciences, vol. XLII-4/W4, 2017, pp. 117-122. https://doi.org/10.5194/isprs-archives-XLII-4-W4-117-2017.

[33] Bahi H., Rhinane H., Bensalmia A., Fehrenbach U., Scherer D.: Effects of Urbanization and Seasonal Cycle on theSurface Urban Heat Island Patterns in the CoastalGrowing Cities: A Case Study ofCasablanca, Morocco. Remote Sensing, vol. 8, issue 829, 2016, art. no. 829. https://doi.org/10.3390/rs8100829.

[34] Li L., Tan Y., Ying S., Yu Z., Li Z., Lan H.: Impact of land cover and population density on land surface temperature: case study in Wuhan, China. Journal of Applied Remote Sensing, vol. 8, issue 1, 2014, art. no. 084993. https://doi. org/10.1117/1.JRS.8.084993. 